\title{
THE EFFECT OF THE WHITE PINE WEEVIL ON PLANTATIONS ON THE UNIVERSITY OF NEW BRUNSWICK FOREST
}

\author{
A. S. WEST JR. ${ }^{1 .}$
}

Associate Professor of Biology, Queen's University, Kingston, Ontario.

$\mathrm{T}$ HE WHITE PINE WEEVIL (Pissodes strobi Peck) is a well-known pest throughout most of the range of white pine. The deformation resulting from the activities of this insect is a common sight, particular. ly in plantations. The University of New Brunswick Forest is no exception. Wherever plantations of white pine have been established weevilling has been a factor of importance. There is also evidence of attack on naturally regenerated white pine. Trees which have escaped attack or have recovered sufficiently so that the effects of an attack are no longer noticeable are conspicuous by their rarity.

At one time the area supported a considerable growth of white pine which had reached a large size. Remains of rotting stumps up to three feet in diameter are common on white pine sites throughout the forest. In a consideration of tree species for planting purposes white pine is a natural choice since climatic and edaphic factors are favourable and the value of the species is recognized.

The establishment of white pine plantations on the University of New Brunswick Forest was first proposed in 1924. A cooperative project involving the University Department of Forestry, the Provincial Department of Lands and Mines, and the Dominion Entomological Laboratory was sug. gested. The objective was to find out under what conditions white pine would grow free from weevil injury. It has been observed that in old growth stands pine apparently escaped injury by coming up in small openings provided by windfalls. Specifically two ideas were to be tested: one was to find out if injury-free white pine could be grown to an age of 50 years or more by planting 3-year transplants in spaces provided by cutting small trees; the second was to find out if injury-free pine could be grown by planting 3-year transplants under a young temporary shade tree such as birch or poplar.

Dr. H. J. MacAloney, of the United States Department of Agriculture, Bureau of Entomology and Plant Quarantine, was associated with the initiation of this project. Records of the progress of the experiments are given in the Annual Reports of the Division of Forest Insects, Dominion Entomological Laboratory, Fredericton.

In May, 1926, five plantations, varying in size from $1 / 8$ to 1 acre, were established under conditions ranging from open field to heavy shade. Examinations during the following summers showed that mortality was negligible. On several of the plots as many as 90 per cent of the terminals were nipped off during the fall. Squirrels were suggested as the probable cause of this injury.

1Formerly Professor of Forest Entomology, University of N^w Brunswick, Fredericton,N.B. 
In 1928 the decision was made not to replace trees which were stunted or had died. In that year an additional plot was established and in 1930 a 1 -acre planting was made. In 1930 only 2 of the plots were worthy of examination. On the other areas nearly all of the seedlings had been destroyed by animal damage. Thus of the total of 7 plots only 2 have been followed in detail. One of these is a 1-acre plot established in 1926. Mixed hardwood growth was cut for firewood and the area was cleared of slash prior to planting. The coppice growth has been cut back twice on parts of this area. Initial growth was good but many trees have since been suppressed and in general weevilling has been severe. Blister rust infections are numerous at the present time. Detailed records of injury on this plot are being tallied by the staff of the Dominion Entomological Laboratory.

The other plot whose development has been followed in detail is the approximately 1 -acre plantation established in 1930. Until 1940 observations were made under the direction of $\mathrm{L}$. J. Simpson whose cooperation in making his data available is greatly appreciated. Since 1940 the area has been used as a study plot by students in Forest Entomology at the University of New Brunswick. The writer is indebted to Professor H. E. Videto for continuation of observations during 1943 and 1944.

This 1-acre plantation was established in an open field where the trees were planted in furrows. Approximately half the area was planted on a 4 by 4 spacing. The other half of the area was planted with 8 foot spacing staggered along rows 4 feet apart. In this portion of the plantation the alternate spaces were left for poplar cuttings. A small section of the latter area is approximately 100 yards removed from the main body of the stand but on a similar site.

Planting stock consisted of 3-year old white pine transplants supplied from the Provincial Nursery in Fredericton. This stock was unthrifty as the result of a heavy infestation of Adelges pinicorticis Fitch which caused the plants to have a shrubby character. Some of the stock was dipped in a Sunoco and Volck oil mixture but examination in the fall revealed no difference between treated and untreated trees.

In 1931 approximately 400 Populus deltoides cuttings were planted in the alternate spaces of half the area. The majority of these cuttings did not grow and none have survived.

The utilization of this plantation as a study plot has resulted in the accumulation of detailed records of weevil attack, mortality, growth and of injurious factors other than the white pine weevil. The following discussion is intended to give a general picture of the condition of this plantation. Although data are available detailed analysis of various possible cor. relations are not justifiable in view of the poor condition of the stand and the obvious lack of any considerable number of crop trees. The picture constitutes a record of the development of an untreated stand. Other than the pruning of the lower 4 to 6 feet of the bole in order to make 
individual trees accessible the stand has not been disturbed and no control measures have been practised.

For purposes of analysis the stand has been divided into four sections, based on original spacing and present distribution of surviving trees.

Section A.- -the separate portion of the plantation, $8 \times 4$, staggered spacing.

Section B.-the portion of the main stand with $8 \times 4$, staggered spacing.

Section C.- - portion of the stand with $4 \times 4$ spacing where mortality has created numerous openings.

Section D.- the remainder of the portion of the stand with $4 \times 4$ foot spacing where mortality has been more evenly distributed and openings are not as apparent.

Condition of Plantation in SpRing of 1946

Table I presents the incidence of weevil attack by years since 1932 . Detailed records were not taken prior to 1941. The older records of weevil attack are based on the presence of stubs of killed leaders and are felt to be reasonably accurate. Of necessity the percentage of trees weevilled during the period 1932.1940 is based on the number of trees living in 1941. As will be shown presently, approximately one-third of the trees planted had died during this period. No attempt was made to secure a weevil attack record on dead trees. For the period 1941-1945 the percentage of trees weevilled is based on the number of trees living each year.

Weevil attack has been distinctly more severe in the more widely spaced portions of the plantation (Sections $A$ and $B$ ), particularly in the separate (A) section where as many as 60 per cent of the trees were attacked in a single year. On the other hand the densest portion of the stand (Section D) has been least attacked. Density has long been recognized as a factor closely related to weevil injury.

Table I

INCIDENCE OF WeEvilling by YeARs-Per Cent

\begin{tabular}{lcccrr} 
Year & \multicolumn{5}{c}{ Section } \\
1932 & A & B & C & D & Total \\
1933 & 8.3 & 1.6 & 3.1 & 2.0 & 2.7 \\
1934 & 20.4 & 6.4 & 5.9 & 8.9 & 7.9 \\
1935 & 24.2 & 6.4 & 5.9 & 6.2 & 7.3 \\
1936 & 23.2 & 15.5 & 8.3 & 7.1 & 10.9 \\
1937 & 20.4 & 13.4 & 8.7 & 6.2 & 9.9 \\
1938 & 38.9 & 21.6 & 20.0 & 10.2 & 18.9 \\
1939 & 33.4 & 23.5 & 15.8 & 9.3 & 16.9 \\
1940 & 55.5 & 32.4 & 25.7 & 16.6 & 27.3 \\
1941 & 43.5 & 41.0 & 32.9 & 32.1 & 34.8 \\
1942 & 51.9 & 47.0 & 42.6 & 35.9 & 41.4 \\
1943 & 59.9 & 33.1 & 27.4 & 33.6 & 32.3 \\
1944 & 39.0 & 25.9 & 18.8 & 9.8 & 19.4 \\
1945 & 27.6 & 12.1 & 11.3 & 13.6 & 13.5 \\
& 35.9 & 15.9 & 10.3 & 9.2 & 13.7
\end{tabular}


In addition to leaders being attacked a certain amount of weevilling of laterals has occurred. This, however, has been insignificant other than as a factor contributing to increase of population.

The effects of a single weevil attack may be outgrown by a tree but repeated attacks result in badly deformed trees which develop into "cabbage" pines. During the period 1932-1945, 85.9 per cent of the trees which were alive in the fall of 1945 were weevilled. Table II shows the frequency of weevilling of individual trees. As would be expected the more widely spaced portions (Sections A and B) have suffered a higher proportion of repeated weevil attacks.

Table II

\section{Frequency of Weevilling of Individual Trees-Per Cent \\ Section}

$\begin{array}{cccccr}\begin{array}{c}\text { Number times } \\ \text { weevilled }\end{array} & \begin{array}{c}\mathrm{A} \\ (4 \times 8)\end{array} & \begin{array}{c}\mathrm{B} \\ (4 \times 8)\end{array} & \begin{array}{c}\mathrm{C} \\ (4 \times 4)\end{array} & \begin{array}{c}\mathrm{D} \\ (4 \times 4)\end{array} & \text { Total } \\ 0 & 2.0 & 6.8 & 17.8 & 19.4 & 14.1 \\ 1 & 3.0 & 14.0 & 21.7 & 24.5 & 19.0 \\ 2 & 8.1 & 19.9 & 20.1 & 24.2 & 20.3 \\ 3 & 10.1 & 20.5 & 17.3 & 18.9 & 18.1 \\ 4 & 22.2 & 16.8 & 11.0 & 8.2 & 12.6 \\ 5 & 14.2 & 12.4 & 7.9 & 2.7 & 8.0 \\ 6 & 20.2 & 5.9 & 2.8 & 1.3 & 4.6 \\ 7 & 9.1 & 3.1 & 1.2 & .5 & 2.1 \\ 8 & 9.1 & .3 & .2 & - & .9 \\ 9 & 2.0 & .3 & - & .3 & .3\end{array}$

Adult weevils tend to select the most vigorous and taller trees for oviposition. Hence the effect of weevil injury tends to level the height of the stand. Table III gives the average heights and diameters for the stand in the fall of 1945 .

\section{Table III}

\section{Average Height and Diameter Growth}

Section

$\begin{array}{ccccccc} & \text { A } & \text { B } & \text { C } & \text { D } & \text { Total } & \text { Red pine } \\ \text { Height, fall, } 1945 & 16.8^{\prime} & 16.7^{\prime} & 17.4^{\prime} & 17.4^{\prime} & 17.2^{\prime} & 17.3^{\prime}\end{array}$

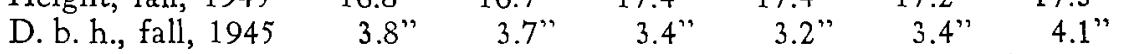

Trees in the more widely spaced portions of the stand tend to be somewhat, but probably not significantly, shorter and also greater in diameter. This would be a natural result of density. Comparative figures are given for a nearby plantation of red pine established a year later than the white pine. The 6.8 per cent non-weevilled trees in Section B had an average height of 14.8 feet and an average diameter of 2.62 inches as contrasted with 16.7 feet and 3.7 inches respectively for all trees in the section. An analysis of Section $\mathrm{O}$ shows a similar condition to be true.

The effect of repeated weevil attacks can further be shown by the frequency of forked trees as is done in Table IV. 
WHITE PINE WEEVIL-WEST

\section{Table IV \\ Frequency of Forked* Trees-Per Cent \\ Section}

$\begin{array}{ccrrrr}\text { Number stems } & \text { A } & \text { B } & \text { C } & \text { D } & \text { Total } \\ 1 & 66.7 & 79.0 & 92.0 & 96.3 & 87.8 \\ 2 & 28.3 & 19.8 & 8.0 & 2.7 & 11.2 \\ 3 & 3.0 & 1.2 & - & .7 & .8 \\ 4 & 2.0 & - & - & .3 & .2\end{array}$

* Forks counted below d.b.h.

Only those forks below d.b.h. have been tallied, representing injury during the early years of plantation. Most trees which develop more than a single stem from near the base of the tree have little chance of producing any valuable wood. Again, a higher proportion of deformation is evident in the more widely spaced portions of the plantation. The development of multiple leaders above d.b.h. is also common. In the course of ten years the leader of a tree may shift from one main stem to another several times.

Since the establishment of the plantation more than 40 per cent of the trees have died. Table $\mathrm{V}$ summarizes the mortality in the several sections and for the stand as a whole.

Table V

MORTALITY

Spacing

\begin{tabular}{ccrrr}
\multicolumn{5}{c}{ Section } \\
A & B & C & D & Total \\
$4 \times 8 *$ & $4 \times 8^{*}$ & $4 \times 4$ & $4 \times 4$ & \\
146 & 551 & 750 & 627 & 2074 \\
108 & 361 & 471 & 421 & 1361 \\
26 & 34 & 37 & 33 & 34 \\
99 & 330 & 428 & 375 & 1232 \\
8 & 9 & 9 & 11 & 10 \\
32 & 40 & 43 & 40 & 41
\end{tabular}

Approximate no. trees planted

No. trees alive, fall, 1941

\% mortality through 1941

No. trees alive, fall, 1945

$\%$ mortality 1942.45 , incl.

\% mortality through 1945

* Spacing staggered in alternate rows

Section A, though most severely weevilled, shows the best survival. Mortality is not necessarily associated with weevil attacks which in themselves are seldom responsible for the death of trees. The importance of mortality relates to its effect on spacing of the remaining trees. As previously indicated this mortality has been somewhat grouped in Section $\mathrm{C}$ as opposed to a more even distribution in Section D. The greater density of the latter section can be associated with the lower incidence of weevil attack.

A number of factors have been associated directly or indirectly with mortality. Unfortunately, since no records were kept during the early years of the plantation, no information is available to indicate initial survival. It may be assumed that some stunted, suppressed trees, heavily infested with Adelges pinicorticis, died. This insect is still present in scattered occurrence in the plantation. 
Animal damage to the base of trees has frequently occurred. Evidence has been found of injury by mice, rabbits, and occasionally by porcupines. In a number of cases death of a tree has clearly been due to its having been girdled. Associated with girdling injury is the presence of insect borers in the bark. These have been investigated by the Dominion Entomological Laboratory and are probably secondary in nature.

More recently blister rust has become a factor of importance. The results of a survey of the incidence of blister rust in the spring of 1946 are given in Table VI. This disease is of common occurrence on white pine throughout the forest and Ribes are abundant. Hence it is likely that conditions favor an increase in the incidence of the disease.

\section{Table VI}

Incidence of Blister Rust, Spring 1946-Per Cent

Section

$\begin{array}{ccccc}\text { A } & \text { B } & \text { C } & \text { D } & \text { Total } \\ 14.1 & 15.8 & 10.7 & 9.6 & 12.0\end{array}$

The fact is stressed that no control measures have been undertaken on any plantations. The plantation which has been discussed in detail together with the other surviving plantation are past the stage warranting control.

An ambitious program was undertaken two decades ago. It is unfortunate that circumstances did not permit a closer check of the plantations. It is obvious that unless control measures are practised it is inadvisable to plant white pine in this area which can be classed as "weevil country". Since white pine is a valuable species; formerly abundant and capable of good growth, the writer feels that further study should be made of the possibility of growing the species under conditions which will prevent serious weevil injury. A program of Ribes eradication is a must before any such study can be contemplated. 